\title{
Editorial
}

\section{From CONFEDERACY TO CONVOY: ThOUghtS ABOUT THE FINALITY OF THE UNION AND ITS MEMBER STATES}

Just ten years ago, on 12 May 2000, German foreign minister Joschka Fischer gave his famous speech entitled From Confederacy to Federation, in which he called for European political integration by way of a new constituent Treaty, for full parliamentarisation of the Union and for a real executive government. All this, he considered, was needed for the Union to be able to admit the Eastern European states and safeguard its action capacity. The outcome would be 'a lean European Federation, but one capable of action, fully sovereign, yet based on self-confident nation-states, and it would also be a Union which the citizens could understand, because it would have made good its shortfall on democracy.'

According to their nature, things have taken a somewhat different course from what Fischer envisaged. Much sooner than he had expected, the new member states joined and the Union embarked on its constitutional venture. Fischer's idea of a 'deliberate political act to re-establish Europe', on the other hand, took ten years to become reality. And it would not do so in the form of a deliberate political act of re-establishment, but as a traditional amending treaty.

Still, in this Lisbon Treaty, Fischer's ideas are alive. This is one more good reason to give them some attention. They are alive both in the form of facts that have meanwhile obtained and in the form of remaining questions.

As to an obtained fact one may consider the choice that actually has been made of allocating core executive power. Fischer had said: 'Either one can decide in favour of developing the European Council into a European government, i.e., the European government is formed from the national governments, or - taking the existing Commission structure as a starting-point - one can opt for the direct election of a president with far-reaching executive powers. But there are also various other possibilities between these two poles.' The facts have opted for developing the European Council into a European government, in which the European Commission is involved through its president.

As to remaining questions, probably the principal one for scholarship is that of the relationship between the Union and its member states. Fischer had correctly argued: 'The main axis for such a European constitution will be the relationship 
between the Federation and the nation-state.' This is perfectly true and it is equally true that little in the matter seems to have been settled. The Lisbon Treaty has introduced a system of division of competences between the Union and the member states; it has reasserted the principles of conferral, of subsidiarity and of proportionality. But no one will venture now to say that these principles exhaust the subject. It is no exaggeration to see the relationship between the Union and its member states as the dark and most contested continent of European Union scholarship. Even in only its legal aspects or elements, the relationship is defined in part by international law, in part by domestic law of the member states and in part by primary and secondary Union law. In the mere constitutional sphere, there is much more to the relationship than just law. The member states are at once masters and servants of the Union, and they are many things in between.

On 25 February 2010, the European Council president Van Rompuy gave a principled speech in Bruges which, in many ways, was inspired by the same analysis that Fischer made ten years earlier. Like him, Van Rompuy drew attention to the difference of decision-making methods between economic and political integration. 'In foreign policy you need quick decision and action, whereas our original working method was devised, and works well, as a rule making procedure. Progress in European foreign policy has relied largely on the impulse and the authority of the Heads of State or Government. ... In foreign affairs, and especially in security policy, the States ... themselves are the actor and they take responsibility. ... Therefore we should not be surprised that the more the Union deals with foreign affairs, in the coming decade, the more certain differences in attitude between Member States rise to the surface.'

Van Rompuy's contribution to conceptualising the resulting situation has the form of a metaphor. 'As foreign policy is concerned, I would prefer to compare the European Union to a convoy. Think of a convoy of 27 ships finding its way across the geopolitical waves. ... The wind makes them drift apart some of the time, gets them to sail in the same direction at other times. ... What you don't see is what the 27 captains know very well: under the waterline, their ships, like the 27 EU governments, are all connected, economically and monetarily. ... This European convoy does not have one single captain. Recently it acquired a permanent President, however. One of his tasks ... is to preside over the meetings of the 27 captains and to find a consensus about where to go. To re-establish a sense of strategic direction.'

There is a useful distinction, implicit in this metaphor, between what in the Union happens, exists and evolves aboveboard, and what happens beneath the surface. If the 'ships of state' (Plato's old metaphor, which has shed its authoritarian connotation), are tied up beneath the waterline, it is through their economies, their cultures, their interdependence, their administrations and hopefully even their 
populations. But metaphors are not meant to serve or provide doctrinal precision. What this image does well is to express by default how little progress has been made in constitutional scholarship on Fischer's central and unresolved question of the relationship between the convoy and the ships or, in other words: the relationship between the Union and its member states.

The relationship between the Union and the states is rich, complex and full of paradoxes; this much is certain. Member states are under Union obligations and at the same time they are the Union's masters. Member states administer Union policies while at the same time, as part of the Union government, they decide on these policies. Member states as treaty masters are above and outside the Union, and at the same time they are being ordered around and scrutinised by Union institutions such as the Commission, the European Council and the Court of Justice. Member states' governments are subject to Commission control and at the same time together they form a sort of European government of which the Commission is a part. National parliaments scrutinise their own governments and at the same time they are empowered under the Union to scrutinise the Commission. Nationals of the member states are citizens of the Union. All participants are playing several roles at the time. Georges Scelle, author of the idea of 'dédoublement fonctionnel', would have been dazzled by the extent to which his idea applies to the Union.

The picture of the convoy points at an actual web of interconnections. Constitutionally, however, it is puzzling. In the famous image used for the Marshall plan (reproduced on the cover of Andrew Moravcsik's 1998 book The Choice for Europe) there is a single ship under sail of all the European flags together. ${ }^{1}$

In that perspective, the convoy pictures a regression. But is there regression, really? Much of what Joschka Fischer hoped and looked for ten years ago has materialised, even if in a very different form than he envisaged. The Union is steadily growing to its membership of thirty. There is a form of Union government with democratic credentials, although it is not a parliamentary form of government. The Union is based on states and citizens. All this has been accomplished much by way of practice, often without assistance or even acknowledgement of doctrine. But the relationship between the Union and the member states, or its finality, is still quite unresolved. In this respect we are where we were ten years ago. The convoy image testifies to this.

One may blame the European governments or the states for failing to agree on a finality or final model for their collaborative structure. One may hold that the Treaty embodying some such finality was voted down by the French and the Dutch in 2005. Though there may be some truth to this, it certainly is not the last word.

\footnotetext{
${ }^{1}$ This is drawn from Stephan Leibfried et al., 'Through the Funhouse Looking Glass: Europe's Ship of States', German Law Journal 2009, p. 311-334.
} 
Legal and constitutional structure does not spring and grow from agreement only. In historical fact, an actual structure of authority is mostly based on a succession of agreements but also of other factual developments and of conceptual understanding. The mixture may differ, but the lack of full agreement between participants as to the nature of their collaboration does not make the latter fundamentally flawed, either factually or conceptually. Did the Americans agree about the nature of their federation, in, say 1800? Did they understand what they were getting themselves into?

A somewhat similar question related to the Union's definition was that of its legal personality. On the basis of the Maastricht Treaty, in the negotiations for which this legal personality had not been agreed, member states could hold that legal personality was absent. But under international law, this is merely the subjective side of the matter. Objectively, legal personality also depends on fact, qualified by international law, such as action from the Union bodies and acceptance by others.

European legal doctrine was then right in looking beyond the lack of a voluntary act when inquiring whether Union legal personality existed: this could also arise from Union action on the international plane and acknowledgement by other states. This is in keeping with the Reparation for Injuries Ruling of the ICJ of 1948. And as soon as the Union started to conclude agreements, much of legal doctrine found that legal personality existed. When the states finally acknowledged legal personality for the Union in the Lisbon Treaty, legal doctrine had preceded them by fifteen years. Likewise the Union's constitutional status does not only depend on whether the states have agreed on this or not and it is becoming imperative to look beyond what the member states have managed to agree on as the Union's finality. Like legal doctrine concerning the Union's legal personality, constitutional doctrine should start to sort out the complex relationship between the member states and the Union and look for objective constitutional structure. It should draw on agreement, on action and on other elements of fact, and use not just law but other sources of understanding available in the Western constitutional tradition.

There was a time when the Union's typical ambivalence between its international and its domestic public law status might be thought to be solved some day by its ultimate submission to either one of the two familiar regimes. The Union could revert to the status of an organisation plainly under international law, or it could turn into a state. Or it could hang in between as a suigeneris animal. That time is past. Both revolutionary scenarios are now unrealistic. The in-between situation is quite stable. But as a 'sui generis' animal it defies definition and is only intelligible by experts and to others who are familiar with it through daily practice. That is not an option. 
We as constitutionalists owe it to ourselves and even to the 500 million other citizens of a member state and of the Union at the same time, to come up with a legally and constitutionally readable understanding of the situation. It must not be one suffering from the split between international and domestic public law. It must not mystify the Union as a completely original structure, intelligible only in its own terms. Such understanding should encompass not only the limits but also the logic of the situation; not only its mechanics but also its evolution. It should be intelligible for the public. It should allow for the multiple dualities of loyalty, of function, of legitimacy. It should allow for shared authority. Constitutional thought is well equipped to deal with actual duality and ambivalence. These characteristics of the Union are real and are here to stay.

The relationship between the Union and its member states must be accounted for in its full spectrum, as part of a single, intelligible structure.

That is within reach of constitutional scholarship.

WTE/MC 